\title{
REVITALISASI TAMAN KOTA SIGLI SEBAGAI RUANG PUBLIK YANG BERNUANSA ISLAMI
}

\author{
Revitalization of Sigli City Park As a Public Space with Islamic Nuance \\ Desi Safriana \\ Program Studi Arsitektur, Fakultas Sains \& Teknologi, UIN Ar-Raniry (desisafriana@ar-raniry.ac.id)
}

\begin{abstract}
ABSTRAK
Keberadaan taman kota merupakan hal yang sangat penting dalam perancangan kota. Selain berfungsi sebagai fasilitas publik, taman kota juga sangat penting keberadaannya jika ditinjau dari berbagai aspek. Berdasarkan Rencana Tata Ruang Provinsi Aceh, setiap kabupaten/kota harus memiliki kawasan Ruang Terbuka Hijau (RTH) sebanyak 30\%. Penelitian ini mengambil tempat di Kota Sigli yang merupakan salah satu kecamatan yang berada di Kabupaten Pidie, Provinsi Aceh, Indonesia. Pemerintah Kota Sigli saat sekarang ini sedang melakukan pembangunan di berbagai sisi, salah satunya adalah pembangunan taman kota sebagai fasilitas ruang terbuka hijau dan ruang publik. Taman Kota yang berada di jalan Merdeka, tepatnya di tepian sungai Sigli ini sangat berpotensi untuk mengakomodir kebutuhan masyarakat terhadap kebutuhan akan ruang terbuka atau sarana publik. Namun berdasarkan pengamatan penulis di lokasi, taman kota ini terlihat sepi dari pengunjung, kurang terawat dan disalahgunakan sebagai tempat pembuangan sampah. Hal ini tentunya sangat merugikan bagi masyarakat dan lingkungan, mengingat taman kota ini merupakan fasilitas publik yang harus dioptimalkan dengan baik. Untuk meningkatkan kunjungan dan pemanfaatan Taman Kota Sigli ini maka di perlukan tindakan untuk perubahan atau melakukan revitalisasi. Untuk mengetahui tindakan apa yang mesti dilakukan, maka diperlukan identifikasi persepsi masyarakat kota Sigli mengenai taman tersebut. Untuk itu maka dilakukan penelitian ini guna terciptanya taman pusat kota yang representative bernuansa Islami sebagai bagian ruang publik pusat Kota Sigli. Berdasarkan temuan penelitian, telah direncanakan penataan ulang Taman Kota Sigli yang representative dan bernuansa Islami. Diharapkan penelitian ini dapat memberikan kontribusi bagi Pemerintah dan masyarakat Kota Sigli.
\end{abstract}

Kata kunci: Revitalisasi, Taman Kota, Islami, Sigli.

\begin{abstract}
The existence of a city park is very important in urban planning. In addition to functioning as a public facility, city parks are also very important if viewed from various aspects. Based on the Aceh Provincial Spatial Plan, each Regency/City must have a Green Open Space (RTH) area of $30 \%$. This research takes place in Sigli City which is one of the sub-districts in Pidie Regency, Aceh Province, Indonesia. The Sigli City Government is currently carrying out developments on various sides, one of which is the construction of city parks as facilities for green open spaces and public spaces. The City Park, which is located on Jalan Merdeka, precisely on the banks of the Sigli river, has the potential to accommodate the needs of the community for the need for open space or public facilities. However, based on the author's observations at the location, this city park looks deserted from visitors, poorly maintained and misused as a garbage dump. This is certainly very detrimental to the community and the environment, considering that this city park is a public facility that must be optimized properly. To increase visits and utilization of Sigli City Park, action is needed for changes or revitalization. To find out what actions must be taken, it is necessary to identify the perception of the people of Sigli about the park. For this reason, this research was carried out in order to create a representative city center park with Islamic nuances as part of the central public space of Sigli City. Based on the research findings, it has been planned to reorganize Sigli City Park which is representative and has an Islamic nuance. It is hoped that this research can contribute to the Government and the people of Sigli City.
\end{abstract}

Keywords: Revitalization, City Park, Islamic, Sigli.

\begin{tabular}{lll}
\hline Article History & & \\
\hline Diterima (Received) & $:$ & $17-06-2021$ \\
Diperbaiki (Revised) & $:$ & $29-06-2021$ \\
Diterima (Accepted) & $:$ & $30-06-2021$
\end{tabular}




\section{PENDAHULUAN}

Taman Kota merupakan elemen penting dalam perencanaan sebuah kota. Selain berfungsi sebagai fasilitas publik, taman kota juga sangat penting keberadaannya jika ditinjau dari berbagai aspek. Jika ditinjau dari aspek ekologis taman kota berfungsi sebagai paru-paru kota yang dapat mengurangi tingkat polusi udara di lingkungan, berfungsi sebagai peresapan air untuk mengurangi risiko banjir, kemudian juga sebagai penghasil oksigen yang merupakan kebutuhan utama manusia serta dapat meredam kebisingan dari aktivitas kota. Sedangkan dari aspek sosial taman kota dapat berfungsi sebagai tempat bersosialisasi, berkomunikasi, berolahraga dan berekreasi. Bahkan taman kota juga dapat menjadi landmark yang dapat menjadi ciri khas sebuah kota.

Kota Sigli merupakan salah satu kecamatan yang berada di Kabupaten Pidie. Terletak $112 \mathrm{~km}$ di sebelah timur Banda Aceh, Kota Sigli mempunyai luas $3087 \mathrm{~km}^{2}$. Salah satu misi dari Kota Sigli adalah menjaga keseimbangan lingkungan dan pembangunan berkelanjutan. Hal ini diwujudkan dengan adanya pembangunan taman-taman kota yang berfungsi sebagai fasilitas publik yang sekaligus dapat menjaga keseimbangan alam. Taman kota merupakan bentuk fasilitas sosial yang dikelola pemerintah kota sehingga taman merupakan fasilitas publik yang harus disediakan oleh pemerintah kota. Taman Kota dapat diakses oleh semua warga tanpa ada pungutan biaya.

Penyediaan fasilitas sosial dalam bentuk taman merupakan kebijakan dari pemerintah tentang kepedulian terhadap lingkungan. Kesadaran akan pentingnya lingkungan yang asri dan taman sebagai paru-paru kota serta sarana rekreasi, diwujudkan melalui kebijakan operasional dalam bentuk tamantaman kota (Adi, 2008).

Pemerintah kota Sigli saat sekarang ini sedang melakukan pembangunan di berbagai sisi, salah satunya adalah pembangunan Taman Kota sebagai fasilitas ruang terbuka hijau dan ruang publik. Taman Kota yang berada di Jalan Merdeka, tepatnya di tepian sungai Sigli ini sangat berpotensi untuk mengakomodir kebutuhan masyarakat terhadap kebutuhan akan ruang terbuka atau sarana publik. Namun berdasarkan pengamatan penulis di lokasi, taman kota ini terlihat sepi dari pengunjung, kurang terawat dan disalahgunakan sebagai tempat pembuangan sampah. Hal ini tentunya sangat merugikan bagi masyarakat dan lingkungan, mengingat taman kota ini merupakan fasilitas publik yang harus dioptimalkan dengan baik.
Untuk meningkatkan kunjungan dan pemanfaatan Taman Kota Sigli ini maka di perlukan tindakan untuk perubahan atau melakukan revitalisasi. Untuk mengetahui tindakan apa yang mesti dilakukan, maka diperlukan identifikasi persepsi masyarakat kota Sigli mengenai taman tersebut. Untuk itu maka dilakukan penelitian guna terciptanya taman pusat kota yang representative bernuansa Islami sebagai bagian ruang publik pusat kota Sigli.

\section{METODE PENELITIAN}

Penelitian ini merupakan jenis penelitian deskriptif kualitatif yang digunakan untuk meneliti pada kondisi objek yang alamiah. Penelitian ini dimaksudkan untuk mengangkat fakta, keadaan, variabel dan fenomena-fenomena yang terjadi saat sekarang ketika penelitian berlangsung dan menyajikan dalam bentuk data-data yang bisa di analisa dengan kajian diskripsi. Pada penelitian ini penulis mengambil objek taman kota Sigli untuk diamati dan dianalisis terkait dengan topik pembahasan. Teknik pengumpulan data dilakukan dengan pengamatan dan wawancara dengan dinas terkait dan beberapa pengunjung untuk melihat persepsi masyarakat terhadap taman ini.

\section{HASIL DAN PEMBAHASAN}

Penelitian ini dilaksanakan di Taman Kota Sigli, Jalan Merdeka Kota Sigli, Kecamatan Pidie, Provinsi Aceh, tepatnya berada di depan eks Kantor Bank Rakyat Indonesia (BRI). Taman Kota Sigli merupakan salah satu dari taman-taman yang ada di kota Sigli yang pembangunannya dilakukan untuk menyediakan Ruang Terbuka Hijau (RTH) bagi masyarakat di Kota Sigli.

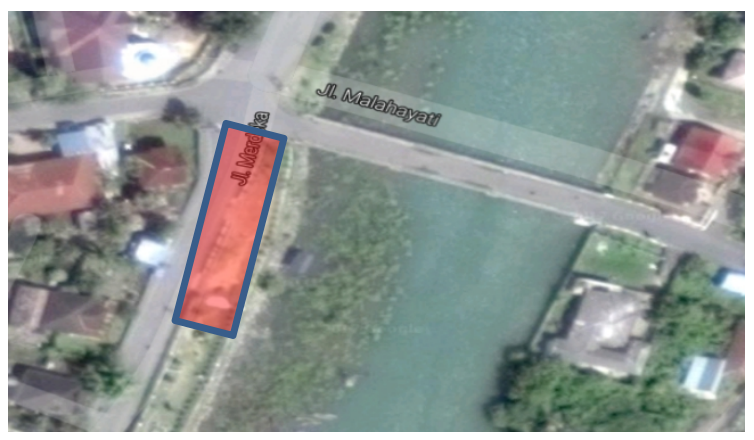

Gambar 1: Peta Kota Sigli

(Sumber: Google Maps, 2020) 
Journal of Architecture - University of Muhammadiyah Aceh Vol: 11 |No: 1 (2021): June

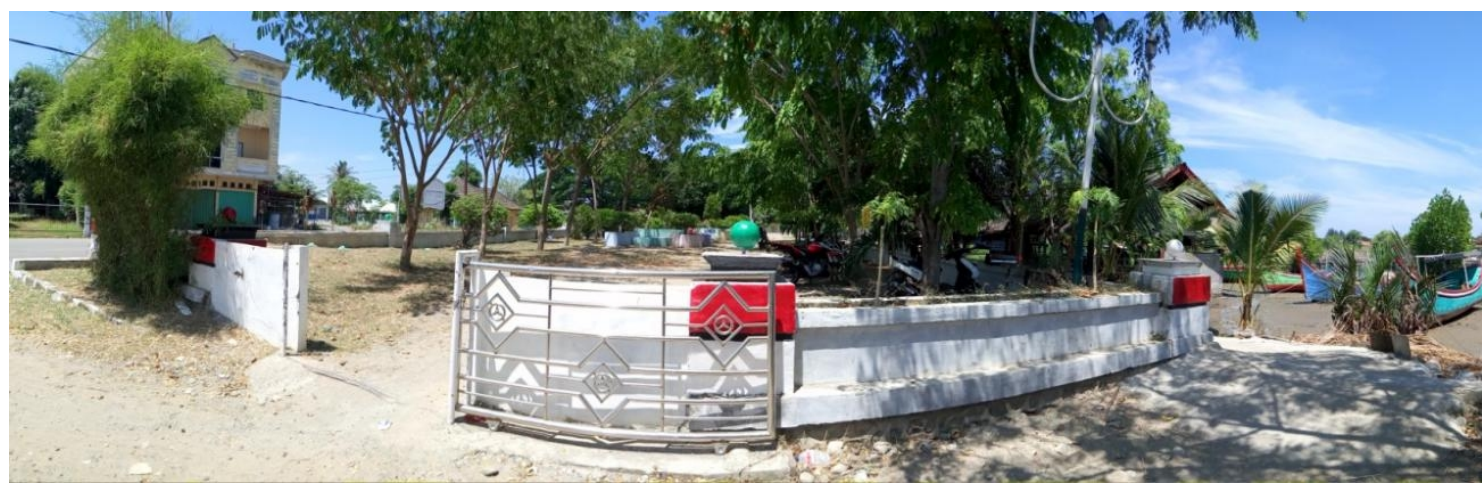

Gambar 2: Foto Taman Kota Sigli

(Sumber: Dokumentasi Penulis)

\subsection{Kondisi Eksisting Taman Kota Sigli}

Taman Kota Sigli saat ini menjadi tempat pilihan alternatif rekreasi bagi masyarakat kota Sigli. Berdasarkan pengamatan penulis, taman kota Sigli ini mempunyai banyak potensi yaitu lokasinya yang sangat strategis berada di pusat kota dan berdekatan dengan pendopo bupati, kawasan wisata laut, dan alun-alun yang sering dikunjungi oleh banyak masyarakat. Potensi lainnya yaitu taman kota ini berada di area tepi air (waterfront) yang dapat dikembangkan menjadi destinasi wisata baru.

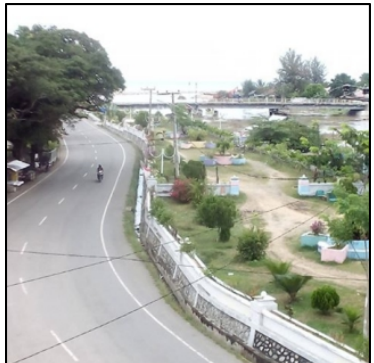

Gambar 3 : Foto Taman Kota Sigli

Sumber : Dokumentasi Penulis

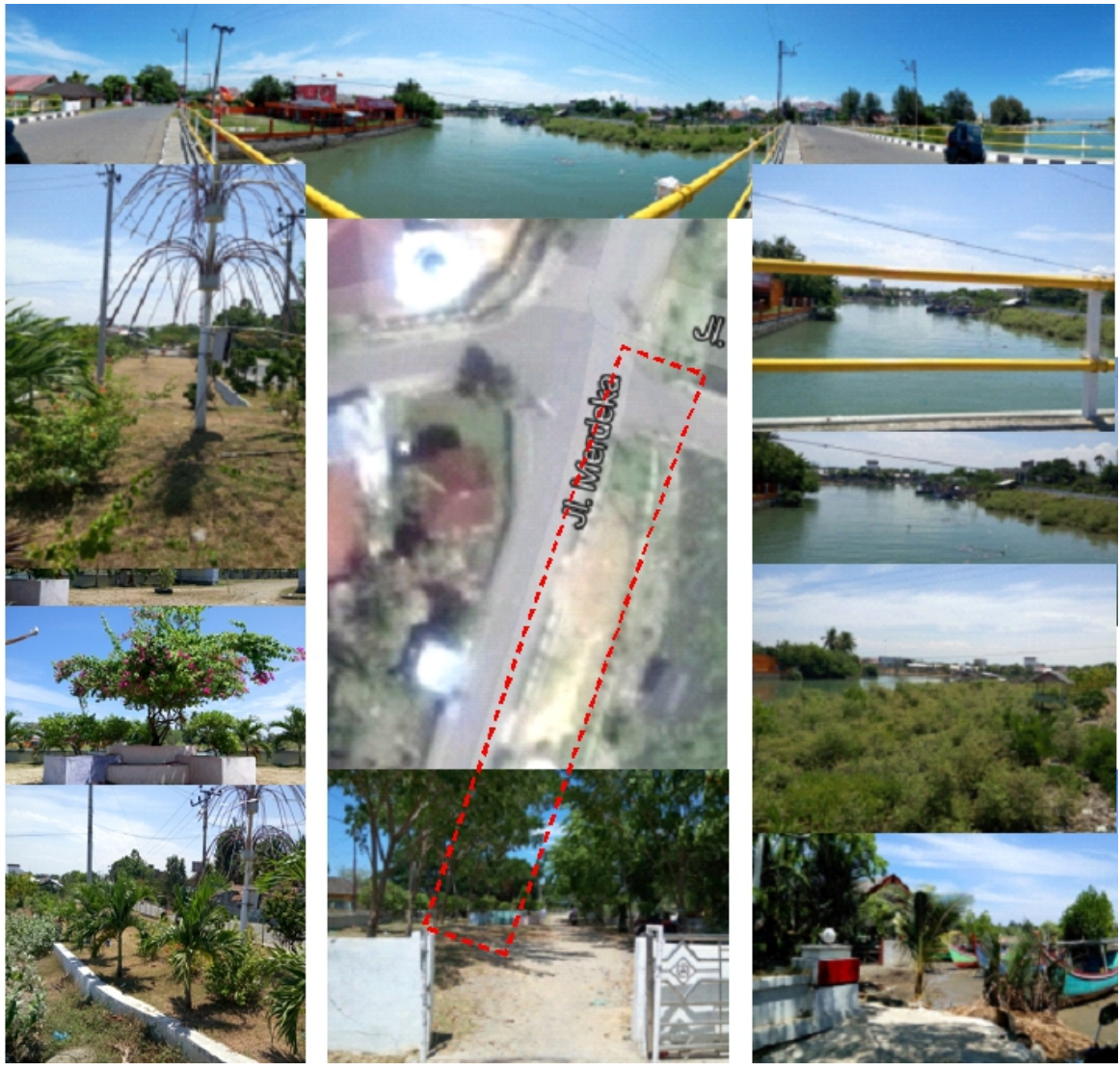

Gambar 4: Foto Kondisi Eksisting Taman Kota Sigl

(Sumber: Dokmentasi Penulis) 


\subsection{Permasalahan Taman Kota Sigli}

Sebagai salah satu taman yang menjadi andalan kota Sigli, sangat disayangkan masih banyak terdapat permasalahan pada taman ini yaitu :

- Kurangnya vegetasi peneduh sehingga menurunkan tingkat kenyamanan pengunjung.

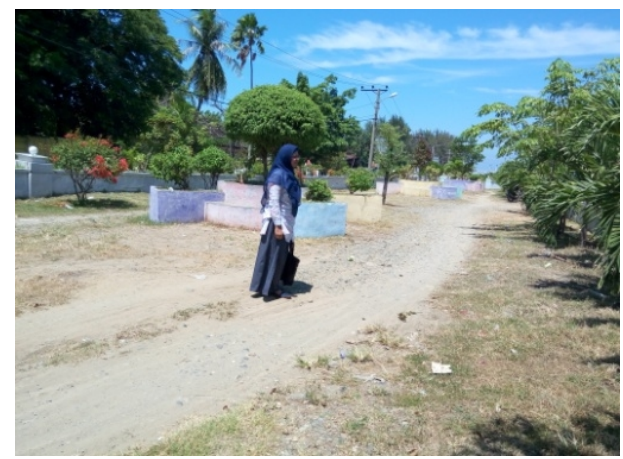

Gambar 5 : Vegetasi Taman Kota Sigli Sumber : Dokumentasi Penulis

- Tidak tersedianya tempat duduk untuk berkontemplasi (tafakkur).

- Tidak adanya penamaan yang spesifik dan ciri khas tertentu pada taman ini.

- Terdapat TPS (Tempat Pembuangan Sampah Sementara) di area depan pintu masuk taman sehingga membuat pengunjung sangat tidak nyaman.
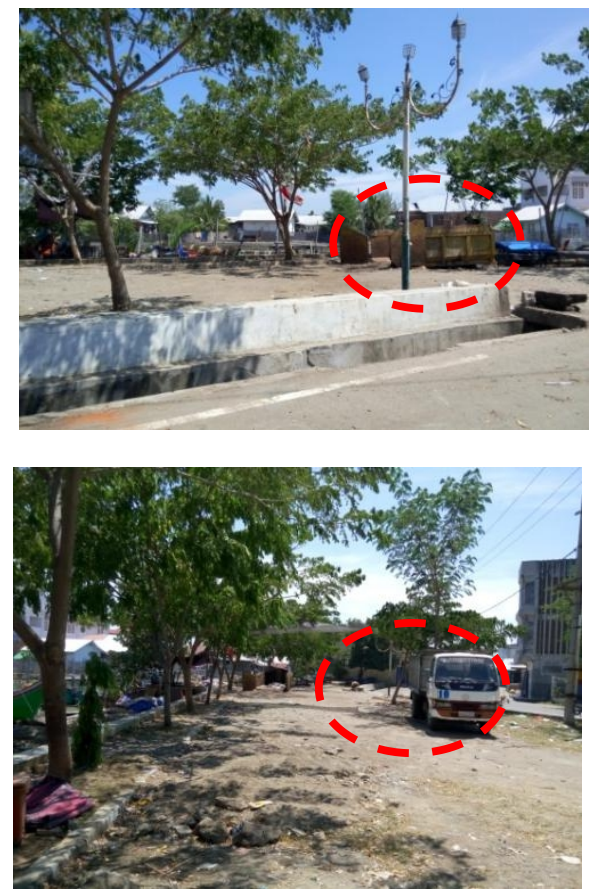

Gambar 6 : TPS yang terdapat di lokasi Sumber : Dokumentasi Penulis

\subsection{Hasil Audiensi dan Wawancara dengan Dinas Terkait}

Pada penelitian ini, penulis juga melakukan pengumpulan data melalui wawancara dengan Dinas terkait seperti: Dinas Pekerjaan Umum, Bappeda, dan Dinas Kebersihan dan Lingkungan Hidup. Berdasarkan hasil wawancara dengan pihakpihak tersebut maka didapatkan informasi bahwa saat ini kawasan Ruang Terbuka Hijau (RTH) di kota Sigli hanya terbangun seluas 5,2 Ha dari total luas yang ditentukan yaitu $141 \mathrm{Ha}$. Salah satu RTH yang dibangun adalah taman-taman yang terdapat di kota Sigli. Namun sayangnya taman tersebut kurang tertata dengan baik dikarenakan keterbatasan anggaran dan lahan. (Responden 1, staf pengaturan dan pembinaan pengelola GIS dan pemetaan, Dinas PU Kota Sigli). Pernyataan lainnya dikemukakan oleh Kasi Pengaturan dan Pembinaan, Dinas PU yang menyatakan bahwa taman kota Sigli tersebut terlalu tinggi sehingga terkesan tidak Islami dikarenakan dapat memberi peluang kepada pelaku pelanggaran syariat. Hal ini juga dikeluhkan oleh masyarakat kota Sigli, sehingga diperlukan perencanaan dan penataan ulang pada taman kota Sigli ini. Selain itu beliau juga mengharapkan dibangunnya beberapa taman lainnya di beberapa lokasi untuk memperindah wajah kota Sigli serta untuk memenuhi kebutuhan RTH. Penulis juga melakukan wawancara dengan Kepala Dinas Kebersihan dan Lingkungan Hidup. Beliau menyatakan bahwa kontainer/TPS yang diletakkan di lokasi taman kota Sigli dikarenakan tidak adanya lahan penampungan dan pembuangan sampah. Oleh karena itu Dinas KLH pada tahun 2018 mendatang merencanakan untuk membeli lahan yang akan digunakan sebagai TPS sehingga tidak akan mengganggu kenyamanan pengunjung taman.

Berdasarkan hasil pengamatan di lapangan dan wawancara dengan dinas terkait, maka diperlukan upaya untuk melakukan revitalisasi pada taman kota Sigli tersebut dengan tujuan mengoptimalisasikan fungsi taman sebagai RTH dan secara estetika dapat memperindah wajah kota Sigli sehingga dapat berfungsi dengan baik sebagai area rekreatif yang islami.

\subsection{Pendekatan Perancangan}

Revitalisasi taman kota Sigli ini dirancang dengan menggunakan konsep penataan taman Islami yaitu dengan meletakkan unsur Islami yaitu : 1. Air

Unsur air sangat penting dalam desain taman Islami, yaitu dianalogikan seperti thaharah (bersuci) 
dan air dapat menenangkan serta menyejukkan. Pada penataan taman ini akan dibuat beberapa air mancur (water fountain) untuk membuat pengunjung merasa nyaman. Selain itu juga dapat menurunkan suhu pada saat cuaca panas. Fountain dibuat berbentuk bintang 8 sudut yang merupakan bagian dari seni Arabesque yang melambangkan sifat kekal Allah SWT (Fireza, 2007).

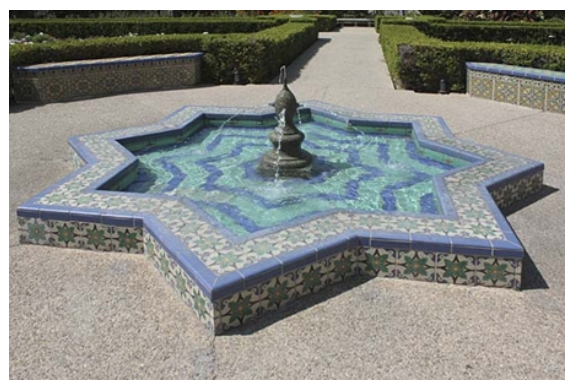

Gambar 7 : Water Fountain

Sumber: www.vitcas.com

\section{Bayangan}

Efek bayangan juga diperlukan pada penataan taman islami. Pada perancangan taman ini efek bayangan dihasilkan dari vegetasi pohon, pergola dan gazebo. Bayangan tersebut diartikan sebagai naungan atau tempat berteduh untuk melakukan tafakkur/kontemplasi.

\section{Warna}

Warna dalam penataan taman Islam juga sangat penting. Pada perancangan taman ini warna akan dihasilkan dari bunga-bunga yang berwarna-warni Selain sebagai unsur estetika, bunga-bunga berwarna ini akan mempengaruhi psikologis pengunjung pada saat melihatnya.

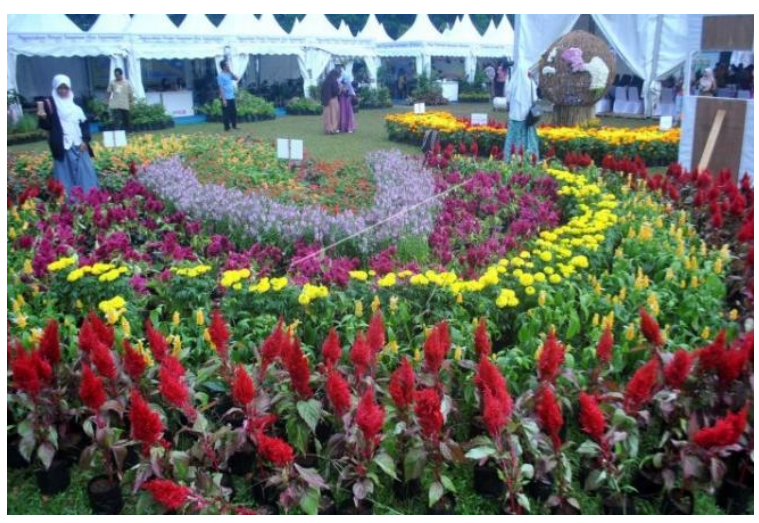

Gambar 8: Ragam warna bunga hias

Sumber : www.antarafoto.com

\section{Suara}

Unsur suara pada perancangan taman ini dapat dimunculkan dari suara gemericik air yang membuat pengunjung merasa nyaman dan tenang serta dapat berileksasi. Selain itu juga didapat dari suara burung-burung endemic yang ditempatkan pada beberapa spot di taman ini.

\section{KESIMPULAN}

Kesimpulan di dapat dari hasil temuan penelitian dan analisis data dengan menggunakan metode kualitatif yang berkaitan dengan revitalisasi Taman Kota Sigli, kemudian dihubungkan dengan temuan lapangan untuk menghasilkan kesimpulan umum. Penelitian ini bertujuan untuk mengetahui permasalahan pada penataan Taman Kota Sigli, mengetahui sistem perencanaan dan penataan taman kota yang dibutuhkan, menemukan solusi dengan membuat konsep revitalisasi yang tepat sehingga taman kota Sigli dapat berfungsi secara optimal.

Menurut pembahasan dan rumusan permasalahan pada penelitian ini, maka kesimpulan dibuat berdasarkan pertanyaan penelitian seperti yang disebutkan di bawah ini:

1. Berdasarkan pengamatan dan wawancara dengan dinas terkait maka dapat disimpulkan bahwa:

- Tidak tertatanya taman kota Sigli ini dikarenakan oleh keterbatasan biaya dan kurangnya kesadaran masyarakat dalam menjaga kebersihan dan kenyamanan.

- Temuan di lapangan menunjukkan bahwa kurang adanya koordinasi antar dinas-dinas terkait pengelolaan dan perawatan taman kota Sigli tersebut, sehingga perlu adanya kerjasama antar dinas dalam hal ini.

2. Sistem perencanaan atau penataan taman kota yang dapat mengakomodir kebutuhan masyarakat:

- Penataan taman kota Sigli disesuaikan dengan kebutuhan masyarakat seperti kebutuhan interaksi sosial, olah raga dan rekreasi.

3. Proses revitalisasi Taman Kota Sigli :

- Proses revitalisasi ini akan dilakukan secara bertahap yaitu diawali dengan relokasi TPS yang ada disekitar lokasi taman.

- Pembersihan area seputaran taman dari sampah yang ada di lokasi dan di sungai yang berada di depan taman.

- Renovasi fasilitas umum yang terdapat di sekitar taman seperti wc umum, tempat parkir dll.

- Penempatan elemen-elemen taman Islami seperti air mancur (water fountain). 
Journal of Architecture - University of Muhammadiyah Aceh Vol: 11 |No: 1 (2021): June

- Penanaman pohon peneduh dan tanaman hias untuk memenuhi unsur warna.

- Penempatan tempat duduk yang nyaman sebagai area interaksi sosial dan kontemplasi.

- Penyediaan tong sampah dengan konsep pemisahan sampah.

- Penempatan burung endemik di salah satu sudut taman kota Sigli untuk menambah kekhasan dari taman ini.
- Serta menyediakan area bermain (playground) bagi anak-anak.

Demikianlah kesipulan dari penelitian ini, diharapkan dapat menjadi rekomendasi konsep revitalisasi taman kota Sigli yang bernuansa Islami sehingga dapat mendukung program pemerintah Kota Sigli dalam penyediaan Ruang Terbuka Hijau.

Berikut adalah usulan perencanaan revitalisasi taman kota Sigli.
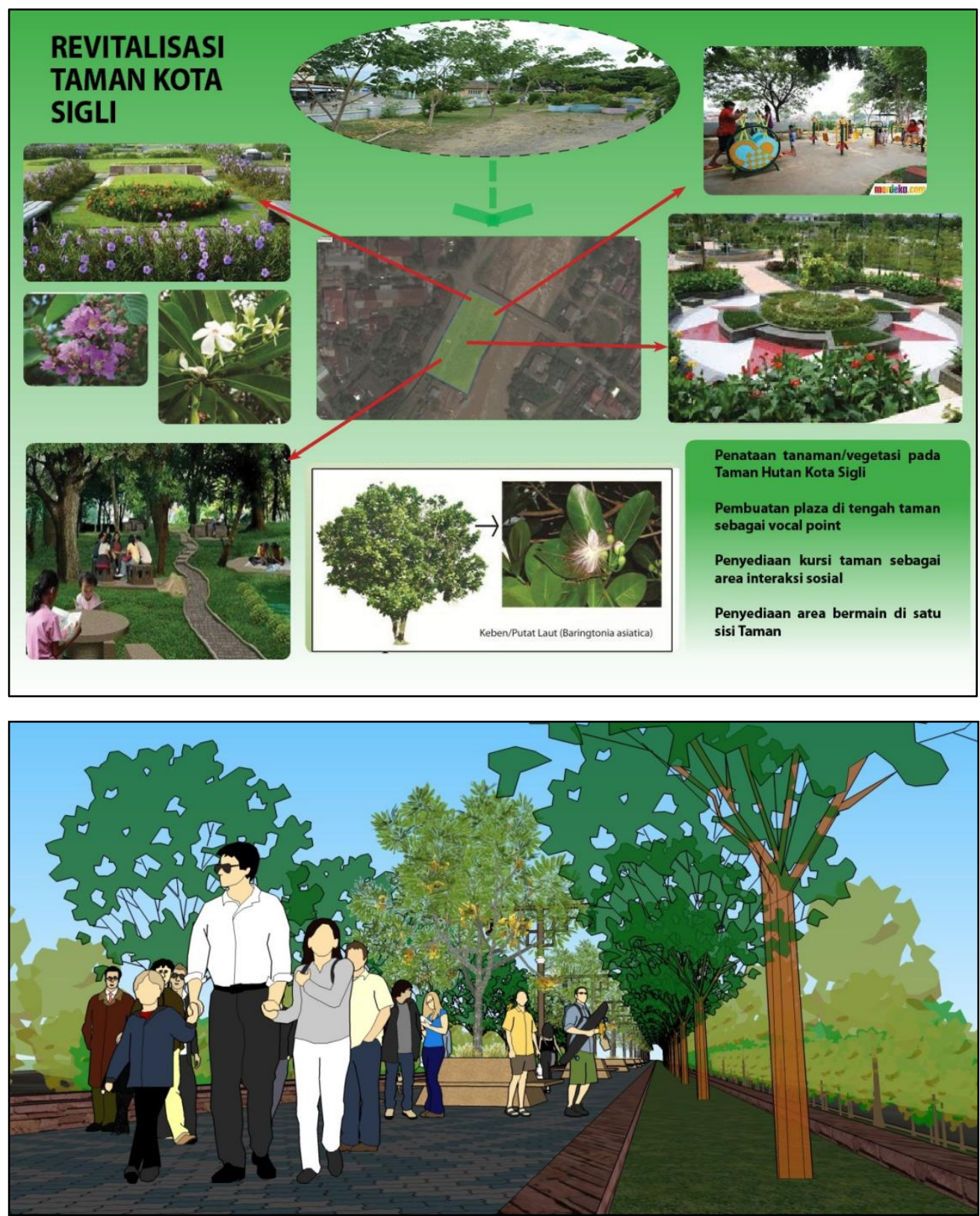

Gambar 9 : Usulan konsep revitalisasi Taman Kota Sigli

Sumber : Dokumentasi Penulis 
Journal of Architecture - University of Muhammadiyah Aceh Vol: 11 |No: 1 (2021): June

\section{DAFTAR PUSTAKA}

Adi, Isbandi Rukminto. (2008). Intervensi Komunitas Pengembangan Masyarakat sebagai Upaya Pemberdayaan Masyarakat. Rajawali Press, Jakarta.

Arifin, Hadi Susilo. (1991). Buku Kenangan Lomba Taman Tingkat Nasional II 1991. Semarang: Biro Kependudukan dan Lingkungan Hidup Jawa Tengah.

Direktorat Jendral Penataan Ruang. (2008). Peraturan Menteri Pekerjaan Umum Nomor 5 Tahun 2008 tentang Pedoman Penyediaan dan Pemanfaatan Ruang Terbuka Hijau di Kawasan Perkotaan. Jakarta: Direktorat Jendral Penataan Ruang Departemen Pekerjaan Umum.

Sasongko, Purnomo Dwi. (2002). Kajian Perubahan Fungsi Taman Kota di Kota Semarang (Tesis). Semarang: Universitas Diponegoro.

Darmawan, (2009). Ruang Publik Dalam Arsitektur Kota. Semarang : Universitas Diponegoro.

Haryono, Paulus. (2007) Sosiologi Kota Untuk Arsitek, Bumi Aksara. Hukum Penataan Ruang dan Penatagunaan Tanah, Rajawali Press, Jakarta 2008.

Al-Quran, Surat Al;Baqarah : 25, Gambaran Taman Surga.

Al-Quran, Surat Al Hijl : 45, Gambaran Taman Surga Hamed, S. El-D. (1994) Paradise on earth: Historical gardens of the arid Middle East. Arab Urban Development Institute.

Lehrman, Jonas Benzion. (1980). Earthly Paradise: Garden and Courtyard in Islam. California: University of California Press.

Clark, Emma. (2004). The Art of The Islamic Garden. Malborough: The Crowood Press.

\footnotetext{
Kutipan Artikel

Safriana, D. (2021), Revitalisasi Taman Kota Sigli sebagai Ruang Publik yang Bernuansa Islami, Rumoh, Vol: 11 (1), 07-13: Juni. DOI: http://doi.org/10.37598/rumoh.v11i1.134
} 